\title{
WATER STORAGE IN WETTED STRIPS UNDER IRRIGATED COFFEE TREES WITH DIFFERENT CRITERIA OF IRRIGATION MANAGEMENT
}

\author{
ALBERTO COLOMBO ${ }^{1}$, LÍViA A. ALVARENGA ${ }^{1}$, MYRIANE S. SCALCO ${ }^{2}$, \\ RANDAL C. RIBEIRO ${ }^{2}$, GISELLE F. ABREU ${ }^{2}$
}

\begin{abstract}
The increasing demand for water resources accentuates the need to reduce water waste through a more appropriate irrigation management. In the particular case of irrigated coffee planting, which in recent years presented growth with the predominance of drip irrigation, the improvement of drip irrigation management techniques is a necessity. The proper management of drip irrigation depends on the knowledge of the spatial pattern of soil moisture distribution inside the wetted strip formed under the irrigation lines. In this study, grids of 24 tensiometers were used to determine the water storage within the wetted strip formed under drippers, with a $3.78 \mathrm{~L} \mathrm{~h}^{-1}$ discharge, evenly spaced by $0.4 \mathrm{~m}$, subjected to two different management criteria (fixed irrigation interval and $60 \mathrm{kPa}$ tension). Estimates of storage based on a one-dimensional analysis, that only considers depth variations, were compared with two-dimensional estimates. The results indicate that for high-frequency irrigation the one-dimensional analysis is not appropriate. However, under less frequent irrigation, the two-dimensional analysis is dispensable, being the one-dimensional sufficient for calculating the water volume stored in the wetted strip.
\end{abstract}

KEYWORDS: irrigated coffee planting, tensiometers, soil water storage.

\section{ARMAZENAMENTO DE ÁGUA EM FAIXAS MOLHADAS SOB CAFEEIROS IRRIGADOS COM DIFERENTES CRITÉRIOS DE MANEJO DE IRRIGAÇÃO}

RESUMO: A crescente demanda por recursos hídricos acentua a necessidade de redução do desperdício de água através de um manejo mais adequado da irrigação. No caso particular da cafeicultura irrigada, que nos últimos anos apresentou crescimento com predominância da irrigação por gotejamento, o aprimoramento das técnicas de manejo da irrigação por gotejamento é uma necessidade. $\mathrm{O}$ manejo adequado do gotejamento depende do conhecimento do padrão espacial de distribuição de umidade no interior da faixa molhada, formada sob as linhas de irrigação. Neste trabalho, foram utilizadas malhas de 24 tensiômetros para determinar o armazenamento de água no interior de faixas molhadas, formadas sob gotejadores, com vazão de $3,78 \mathrm{~L} \mathrm{~h}^{-1}$, uniformemente espaçados de $40 \mathrm{~cm}$, submetidos a dois critérios distintos de irrigação (turno fixo e tensão de $60 \mathrm{kPa}$ ). Estimativas de armazenamento baseadas em análises unidimensionais, considerando apenas variações na profundidade, foram comparadas com estimativas bidimensionais. Os resultados indicam que, com menor turno de irrigação, a análise unidimensional não é adequada. Para maior turno de irrigação, a análise bidimensional é dispensável, sendo a unidimensional suficiente para o cálculo do volume da água armazenada na faixa molhada.

PALAVRAS-CHAVE: cafeicultura irrigada, tensiômetros, armazenamento de água no solo.

\footnotetext{
${ }^{1}$ Departamento de Engenharia, Setor de Engenharia de Água e Solo, Universidade Federal de Lavras, UFLA, C.P. 3037, Lavras MG, acolombo@deg.ufla.br, liviaalvesalvarenga@yahoo.com.br.

${ }^{2}$ Departamento de Agricultura, Universidade Federal de Lavras, UFLA, Lavras - MG, msscalco@dag.ufla.br, randalribeiro8@gmail.com,gfigueiredoabreu@agronomia.ufla.br. 


\section{INTRODUCTION}

The increasing demand for water resources accentuates the need to establish more appropriate irrigation techniques, aiming to reduce waste in the use of irrigation water. In Brazil, where the total area cultivated with coffee reaches 2,057,649 hectares (CONAB, 2011), there is a significant increase in areas with irrigated coffee, with predominant expansion of drip irrigated areas (SOUZA et al., 2006). The preference for drip irrigation is justified by its potential to achieve high uniformity of water application, which allows achieving high efficiency of water application when coupled to an appropriate irrigation management.

As emphasized by CRUZ et al. (2010), the appropriate management of irrigation requires knowledge of the amount of water stored in the soil to allow the application of the required amount of water at the correct time. In the particular case of drip irrigation, the appropriate estimate of the distribution and the amount of water stored inside the wet bulb is also crucial for determining the number of drippers per plant, its location in relation to plant or row of plants (LOPES et al., 2009; NASCIMENTO et. al, 2009) and the wetted area fraction (BARRETOS et al., 2008). However, as described by SOUZA \& FOLEGATTI (2010), these parameters are often neglected. In many cases the negligence in determining these parameters is due to the difficulty of selecting the right type of soil moisture sensors to be used and the difficulty of selecting the proper way to install these sensors in the wetted soil volume.

Among the different techniques available for soil moisture monitoring in irrigated orchards, COELHO et al. (2010) include: measures of the electric/thermal conductivity or capacitance, neutron probe, gamma-ray attenuation, tensiometry, TDR (time domain reflectometry) and FDR (frequency domain reflectometry). Among all these techniques, the tensiometry has excelled. The tensiometer has limitations like their maintenance and for the maximum water tension value that can be measured, which according to BRITO et al. (2009), is about $85 \mathrm{kPa}$. However, according to BAKKER et al. (2007), the reading range of the tensiometers is appropriate because, for most commercial agricultural activities, the amplitude of interest in soil water tension values hardly exceeds $100 \mathrm{kPa}$. Moreover, the development of the called "electronic tensiometer," as described by TEIXEIRA \& COELHO (2005) allows automatic data acquisition and reduces maintenance work in the field.

With regard to the most suitable place for installation of sensors to monitor the characteristics of the wetted volume, COELHO et al. (2010) recommend the region bounded by the effective distance of water extraction (DEe) and the effective depth of water extraction (PEe).

Due to the complexity of the problem of determining the volume of water stored inside wetted soil strips beneath dripper lines, this study aimed to compare, at drip irrigated coffee orchards submitted to two different criteria of irrigation management (fixed interval and tension of $60 \mathrm{kPa}$ ), two techniques for evaluation of water storage inside wetted soil strips: the one-dimensional and the two-dimensional processes.

\section{MATERIAL AND METHODS}

The experiment was conducted in an experimental area of the Department of Agriculture of The University of Lavras (Universidade Federal de Lavras - UFLA) located in Lavras - state of Minas Gerais (MG), Brazil. The geographical coordinates of the area are: $21^{\circ} 15^{\prime} \mathrm{S}$ latitude, $45^{\circ} 00^{\prime} \mathrm{W}$ longitude and altitude of $918 \mathrm{~m}$. The climate of the city is the Cwa type according to Köeppen (mesothermal with mild summers and dry winter). The average annual precipitation and temperature are $1,460 \mathrm{~mm}$ and $20.4^{\circ} \mathrm{C}$, respectively (DANTAS et al., 2007). The experimental area soil type is the Distroferric Red Latosol. The soil was analyzed for its physical, hydric and chemical characteristics before coffee crop planting. Soil samples were collected throughout the experimental area at depths of 0-20 cm, 20-40 $\mathrm{cm}$ and 40-60 $\mathrm{cm}$ (Tables 1 and 2). 
TABLE 1. Soil physical properties of the experimental area.

\begin{tabular}{cccccccc}
\hline \multirow{2}{*}{ Layer } & \multicolumn{3}{c}{ Texture Analysis } & \multirow{2}{*}{ Ds } & \multirow{2}{*}{ MAC } & \multirow{2}{*}{ MIC } \\
\cline { 2 - 4 } & Sand & \multicolumn{1}{c}{ Silt } & Clay & & $\mathrm{g} \mathrm{cm}^{-3}$ & $(\%)$ & $(\%)$ \\
\hline $0-20$ & $(\%)$ & $(\%)$ & $(\%)$ & 53 & 1.2 & 7.5 & 44.7 \\
$20-40$ & 27 & 20 & 68 & 1.1 & 33.6 & 39.1 \\
$40-60$ & 23 & 9 & 68 & 0.9 & 31.3 & 33.6 \\
\hline
\end{tabular}

DS - density of soil, MAC - macroporosity, MIC - microporosity.

The planting of the Rubi MG-1192 cultivar was held on January $3^{\text {rd }}, 2001$ under the spacing of $3.0 \mathrm{~m}$ between rows and $1 \mathrm{~m}$ between plants. It was used a drip irrigation system with a lateral line to at each planting line. The lateral lines were assembled with compensating drippers with a $3.78 \mathrm{~L} \mathrm{~h}-1$ discharge, spaced by $0.4 \mathrm{~m}$ in line, forming a wetted strip along the planting rows.

TABLE 2. Soil chemical properties of the experimental area.

\begin{tabular}{|c|c|c|c|c|c|c|c|}
\hline \multirow{2}{*}{ Characteristics } & \multicolumn{3}{|c|}{ Layers $(\mathrm{cm})$} & \multirow{2}{*}{ Characteristics } & \multicolumn{3}{|c|}{ Layers $(\mathrm{cm})$} \\
\hline & $0-20$ & $20-40$ & $40-60$ & & $0-20$ & $20-40$ & $40-60$ \\
\hline $\mathrm{P}\left(\mathrm{mg} \mathrm{dm}^{-3}\right)$ & $41.0 \mathrm{~A}$ & $33.0 \mathrm{~A}$ & $5.0 \mathrm{~B}$ & $\operatorname{Mn}\left(\mathrm{mg} \mathrm{dm}^{-3}\right)$ & $2.2 \mathrm{M}$ & $1.5 \mathrm{M}$ & $1.0 \mathrm{~B}$ \\
\hline $\mathrm{K}\left(\mathrm{mg} \mathrm{dm}^{-3}\right)$ & $62.0 \mathrm{M}$ & $42 \mathrm{~B}$ & $33.0 \mathrm{~B}$ & Iron $\left(\mathrm{mg} \mathrm{dm}^{-3}\right)$ & $36.9 \mathrm{~A}$ & $35.3 \mathrm{~A}$ & $20.8 \mathrm{~A}$ \\
\hline $\mathrm{Ca}\left(\mathrm{cmolc} \mathrm{dm}^{-3}\right)$ & $4.9 \mathrm{~A}$ & $2.3 \mathrm{M}$ & $1.5 \mathrm{~B}$ & S. B. $\left(\mathrm{cmolc} \mathrm{dm}^{-3}\right)$ & $7.2 \mathrm{~A}$ & $3.5 \mathrm{M}$ & $2.3 \mathrm{M}$ \\
\hline $\operatorname{Mg}\left(\operatorname{cmolc} \mathrm{dm}^{-3}\right)$ & $2.1 \mathrm{~A}$ & $1.1 \mathrm{~A}$ & $0.7 \mathrm{M}$ & $\mathrm{t}\left(\mathrm{cmolc} \mathrm{dm}^{-3}\right)$ & $7.2 \mathrm{~A}$ & $3.8 \mathrm{M}$ & $2.9 \mathrm{M}$ \\
\hline $\mathrm{Al}\left(\mathrm{cmolc} \mathrm{dm}^{-3}\right)$ & $0.0 \mathrm{~B}$ & $0.3 \mathrm{M}$ & $0.6 \mathrm{M}$ & $\mathrm{T}\left(\mathrm{cmolc} \mathrm{dm}^{-3}\right)$ & $11.2 \mathrm{~A}$ & $9.8 \mathrm{M}$ & $8.6 \mathrm{M}$ \\
\hline $\mathrm{H}+\mathrm{Al}\left(\mathrm{cmolc} \mathrm{dm}^{-3}\right)$ & $4.0 \mathrm{M}$ & $6.3 \mathrm{~A}$ & $6.3 \mathrm{~A}$ & $\mathrm{~m}(\%)$ & $0.0 \mathrm{~B}$ & $7.9 \mathrm{~B}$ & $20.8 \mathrm{M}$ \\
\hline S-sulfate $\left(\mathrm{mg} \mathrm{dm}^{-3}\right)$ & $97.3 \mathrm{~A}$ & $161.8 \mathrm{~A}$ & $201.0 \mathrm{~A}$ & $\mathrm{~V}(\%)$ & $64.2 \mathrm{M}$ & $35.5 \mathrm{~B}$ & $26.6 \mathrm{~B}$ \\
\hline Boron $\left(\mathrm{mg} \mathrm{dm}^{-3}\right)$ & $0.4 \mathrm{M}$ & $0.4 \mathrm{M}$ & $0.3 \mathrm{M}$ & O.M. $\left(\right.$ dag kg $\left.{ }^{-1}\right)$ & $3.5 \mathrm{~A}$ & $2.7 \mathrm{M}$ & $2.2 \mathrm{M}$ \\
\hline Zinc $\left(\mathrm{mg} \mathrm{dm}^{-3}\right)$ & $1.3 \mathrm{~A}$ & $0.7 \mathrm{M}$ & $0.3 \mathrm{~B}$ & & & & \\
\hline
\end{tabular}

Analysis performed at the laboratory of the Department of Soil Science of UFLA. A - high content, M - medium content, B - low content (Commission of Soil Fertility of the State of Minas Gerais, 1999). S.B - sum of basis, t - effective C. T. C., T - C. T. C. with $\mathrm{pH}$ 7.0, $\mathrm{m}$ - saturation by aluminum, V - saturation by basis, O.M. - organic matter.

In each treatment, the spatial distribution of soil moisture within the wetted strip was determined by a single set of tensiometers. The readings of the tensiometers were weekly made from June $9^{\text {th }}$ to December $22^{\text {nd }}, 2009$. As schematized in Figure 1 , in each one of these sets, the tensiometers were installed at depths of $10 ; 15 ; 25 ; 35 ; 45$ and $60 \mathrm{~cm}$, divided into four equidistant planes, parallel to the dripper lines and located at distances of , respectively, $0 ; 10 ; 20$ and $30 \mathrm{~cm}$.

For determining the soil matric potential at a desired depth, tensimeter readings values, in bar, were converted into $\mathrm{cm}$ of water and corrected for the tensiometer ceramic cup installation depth, according to the following equation:

$$
\Psi_{\mathrm{m}}=-\frac{\mathrm{L} 10^{7}}{\gamma}+\mathrm{h}_{\mathrm{c}}
$$

in which,

$\psi \mathrm{m}$ - matric potential in $\mathrm{cm}$;

$\mathrm{L}$ - tensimeter reading in bar;

$\gamma$ - specific weight of water, assumed as $9,806.65 \mathrm{~N} \mathrm{~m}^{-3}$, and

hc - vertical distance between the tensimeter center inserted at the top of the tensiometer and the center of the ceramic cup buried in the soil $(\mathrm{cm})$. 


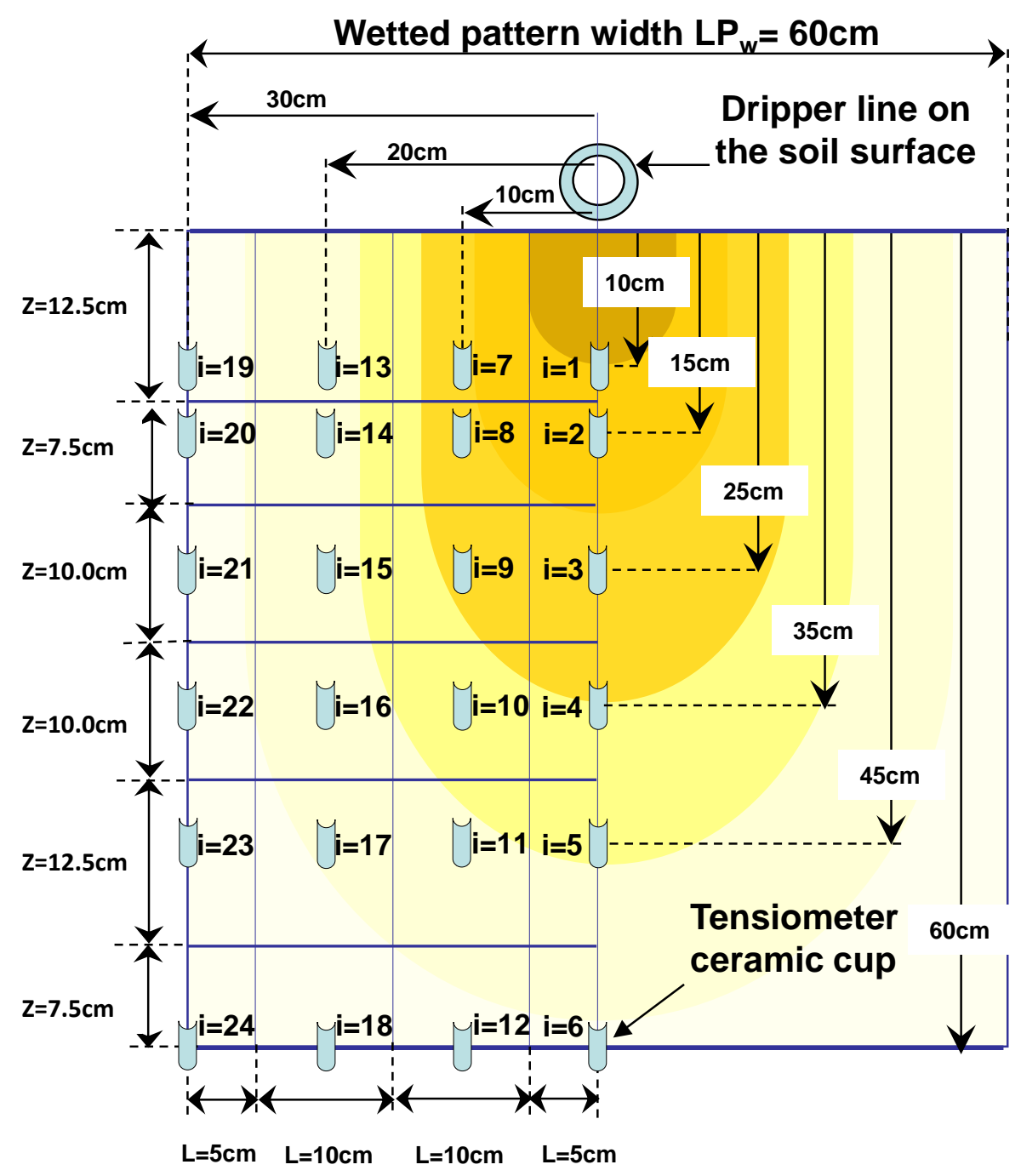

FIGURE 1. Spatial distribution of the tensiometers used for water storage determinations.

Matric potential values, in $\mathrm{cm}$, were converted in to volumetric soil moisture values by using soil water retention curves adjusted to the model proposed by GENUCHTHEN (1980), as shown in eqs. $(2 \mathrm{a})$ and $(2 \mathrm{~b})$ for the layers at the depths of $0-30 \mathrm{~cm}$ and $30-60 \mathrm{~cm}$ :

$$
\begin{aligned}
& \theta_{0-30}=0.3005+\frac{0.2411}{\left[1+\left(0.1653\left|\psi_{\mathrm{m}}\right|\right)^{1.2848}\right]^{0.2217}} \\
& \theta_{30-60}=0.2788+\frac{0.3232}{\left[1+\left(0.1692\left|\psi_{\mathrm{m}}\right|\right)^{1.5872}\right]^{0.3700}}
\end{aligned}
$$

in which,

$\theta_{0-30}$ and $\theta_{30-60}$ - volumetric soil water contents at the matric potential $\psi \mathrm{m}, \mathrm{cm}^{3} \mathrm{~cm}^{-3}$

For the two-dimensional calculation process, in which the readings of all 24 installed tensiometers are considered, water storage within the wetted strip was computed by eq.(3). For the one-dimensional process, in which only the readings of the six tensiometers installed under the irrigation line are considered, water storage inside the wetted strip was computed by eq.(4). The "i" index is used in eq.(3) $(1 \leq \mathrm{i} \leq 24)$ and in eq.(4) $(1 \leq \mathrm{i} \leq 6)$ for identifying tensiometer readings correspond to the positions shown in Figure 1: 


$$
\begin{aligned}
\mathrm{LA}_{\mathrm{B}} & =\frac{2 \sum_{\mathrm{i}=1}^{\mathrm{i}=24}\left(\theta_{\mathrm{i}}\left(\frac{\mathrm{Z}_{\mathrm{i}} \mathrm{L}_{\mathrm{i}} \mathrm{Eg}}{10}\right)\right)}{\mathrm{ELEg} \mathrm{Eg}} \\
\mathrm{LA}_{\mathrm{u}} & =\frac{\sum_{\mathrm{i}=1}^{\mathrm{i}=6}\left(\theta_{\mathrm{i}}\left(\frac{\mathrm{Z}_{\mathrm{i}} \mathrm{LP}_{\mathrm{w}} \mathrm{Eg}}{10}\right)\right)}{\mathrm{ELEg} E}
\end{aligned}
$$

In which,

$\mathrm{LAB}$ - soil water storage based in the two-dimensional analysis, $\mathrm{mm}$;

$\mathrm{LA} u$ - soil water storage based in the one-dimensional analysis, $\mathrm{mm}$;

$\mathrm{i}$ - tensiometer identification index;

$\theta i$ - volumetric soil content correspondimg to the reading of the $i^{\text {th }}$ tensiometer, $\mathrm{cm}^{3} \mathrm{~cm}^{-3}$;

$\mathrm{Li}$-width of the sampling soil volume of the $\mathrm{it}^{\mathrm{h}}$ tensiometer, $\mathrm{cm}$;

$Z i$-thickness (depth) of the sampling soil volume of the $i^{\text {th }}$ tensiometer, $\mathrm{cm}$;

EL - spacing between dripper lines, $\mathrm{m}$;

Eg - spacing between drippers in the lines, $\mathrm{m}$, and

$L P_{w}$ - width of the wetted pattern, $\mathrm{cm}$.

Aiming to evaluate the effect of irrigation management on the moisture gradient inside the wetted strip, water storage was evaluated at two experimental parcels, subject to different criteria of irrigation management that would result in contrasting irrigation frequencies.

One of these experimental parcels was subjected to an irrigation criterion based on a fixed schedule, with irrigation applications, in the absence of rainfall, on Mondays, Wednesdays and Fridays. For this treatment, irrigation depths were computed using a water balance, in which water inputs were the irrigation and effective rainfall and the outputs, the crop evapotranspiration (ETc) and percolation beyond the maximum rooting system depth $(60 \mathrm{~cm})$. The water balance was performed by the RRIGA-GESAI ${ }^{\circledR}$ software with daily data of maximum, average and minimum temperatures; wind velocity; relative air humidity; solar radiation and precipitation recorded by an automatic weather station, METOS brand, model " $\mu$ metos®", installed in the experimental area. In this software, crop evapotranspiration (Etc) is calculated from reference evapotranspiration (ETo Penman Monteith - ALLEN et al., 1998), with daily corrections by the soil water moisture deficit coefficient $(\mathrm{Ks})$, by the crop coefficient $(\mathrm{Kc}=0.9)$, and by the localization coefficient $(\mathrm{KI})$, as described by MONTOVANI et al., 2007. The other parcel was subjected to an irrigation criteria based on a value of soil water tension around $60 \mathrm{kPa}$, as measured on the central part of the wetted strip at a $25 \mathrm{~cm}$ depth. For this treatment, applied depths were based on the soil moisture depletion as determined by the reading of the tensiometers installed on the central part of the wetted strip, at $10 ; 25 ; 40$ and $60 \mathrm{~cm}$ depths.

\section{RESULTS AND DISCUSSION}

Values of precipitation, days of tensiometer readings and accumulated applied irrigation depths observed during the study period (June $9^{\text {th }}$ to December $22^{\text {nd }}, 2009$ ) are shown in Figure 2.

The values, observed during the study period (June $9^{\text {th }}$ to December $22^{\text {nd }}, 2009$ ), of precipitation, reading dates of the tensiometers and the lamina applied accumulated in the two criteria of irrigation management are shown in Figure 2. 


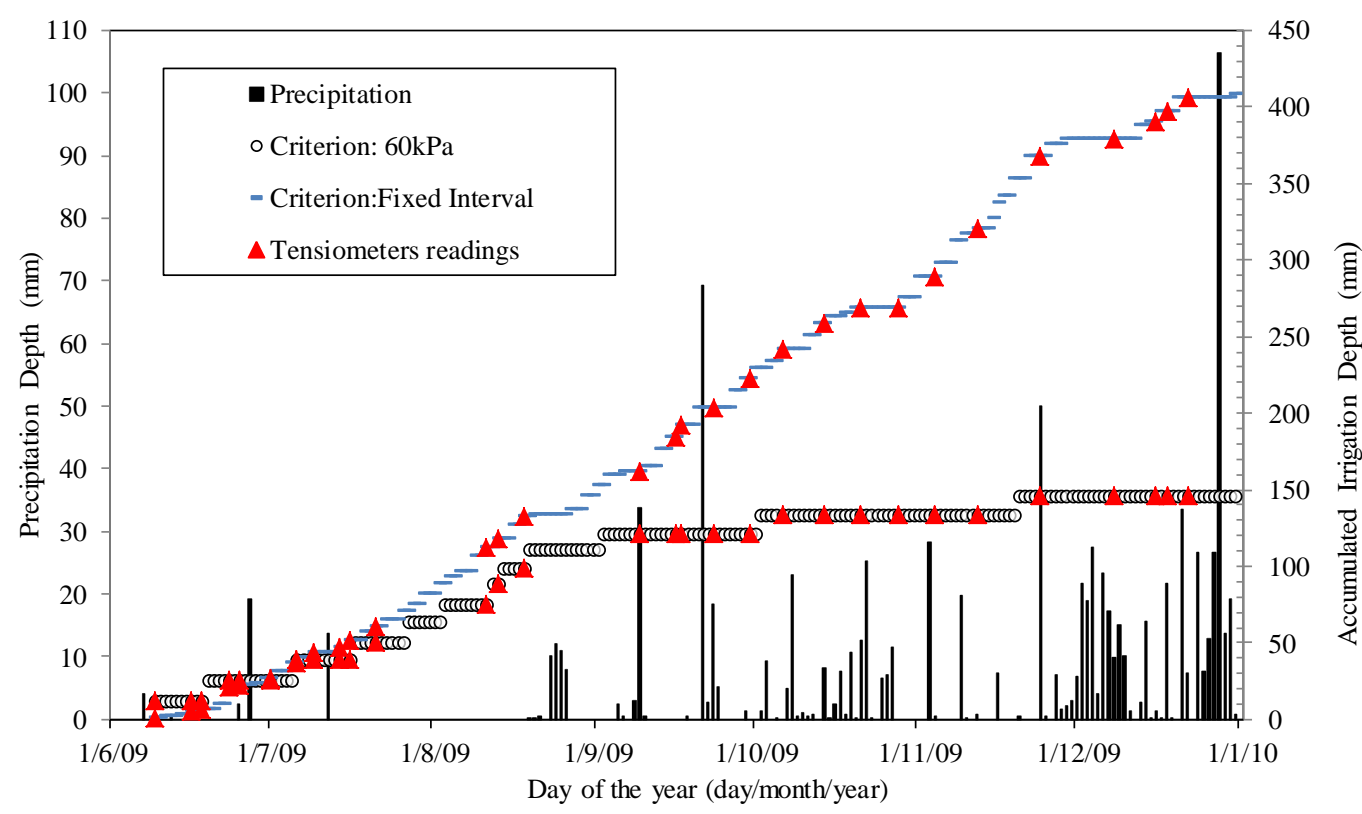

FIGURE 2. Precipitation $(\mathrm{mm})$ and accumulated irrigation $(\mathrm{mm})$ for the two irrigation criteria: $60 \mathrm{kPa}$ tension and fixed turn.

The evolution analysis of applied irrigation depth for each treatment shown in Figure 2 indicates that, during the drier period of the study (06/01/09 to 09/02/09), the difference between accumulated depth values for the two treatments (fixed interval $=152 \mathrm{~mm}$ and $60 \mathrm{kPa}=121.6 \mathrm{~mm}$ ) was approximately $25 \%$ of the accumulated value in the $60 \mathrm{kPa}$ treatment, reproducing a tendency already observed in other comparative studies of irrigation criteria (TAGLIAFERRE et al., 2010; PAVANI et al., 2008). However, due to a higher incidence of rain that occurred from 09/02/2009, the difference between the accumulated depth values in the two treatments (fixed interval $=406 \mathrm{~mm}$ and $60 \mathrm{kPa}=147 \mathrm{~mm}$ ) became of $179 \%$ of the accumulated value observed in the $60 \mathrm{kPa}$ treatment.

For the fixed interval irrigation criterion, in which water applications every Monday, Wednesday and Friday were imposed, except for days with rain, the change in rainfall regime observed during the study did not affect significantly the time interval between two successive irrigations, resulting in a total of 71 irrigations, or an average of one irrigation for every 2.9 days. For the management based on the $60 \mathrm{kPa}$ tension, which was affected by the rain events after 09/02/09, only 11 irrigations events were held, resulting on an average interval of 18.7 days between irrigations.

As regard to the spatial distribution of soil moisture beneath the dripper lines, the data shown in Figure 2, illustrate the possibility of two different scenarios. For the treatment submitted to a fixed irrigation interval, that is based on high frequency irrigation events, the combined effects of rain, soil moisture redistribution, and soil moisture extraction are not able to dissipate, significantly, the lateral soil moisture gradient that, according to OR \& COELHO (1996) and SOUZA \& MATSURA (2004), is formed during water application events. For this scenario, due to the persistence of lateral gradients of soil moisture, water storage estimates based on the twodimensional computation process (eq.(3)) are significantly different from estimates based the onedimensional computation process (eq.(4)). For the $60 \mathrm{kPa}$ tension treatment, due to the large time interval between irrigation events, the combined effect of rain, soil moisture redistribution and soil 
moisture extraction is able to dissipate, significantly, lateral gradients of soil moisture that were formed duringirrigationevents. For this scenario, as lateral gradients of soil moisture are dissipated, water storage estimates based on the two-dimensional process (eq.(3)) did not significantly differ from estimates based on the one-dimensional process (eq.(4)).

As illustrated in Figure 3, a linear relationship between water storage values estimated by the two evaluated calculation processes (one-dimensional - eq.(4) versus two-dimensional - eq.(3)) was observed for the two irrigation management criteria. The good adjustment obtained with the experimental data from the two studied irrigation criteria $\left(\mathrm{R}^{2}=0.963\right.$, for the $60 \mathrm{kPa}$ tension and $\mathrm{R}^{2}$ $=0.833$, for the fixed interval) indicates that reliable linear relations can be established in order to relate estimates of storage obtained by only considering the readings of the six tensiometers, installed at the central plane coincident with the dripper lines, with estimates of water storage obtained by considering the reading of 24 tensiometers installed along four parallel and equidistant planes at the same six depths of the central plane $(10 ; 15 ; 25 ; 35 ; 45$ and $60 \mathrm{~cm})$.
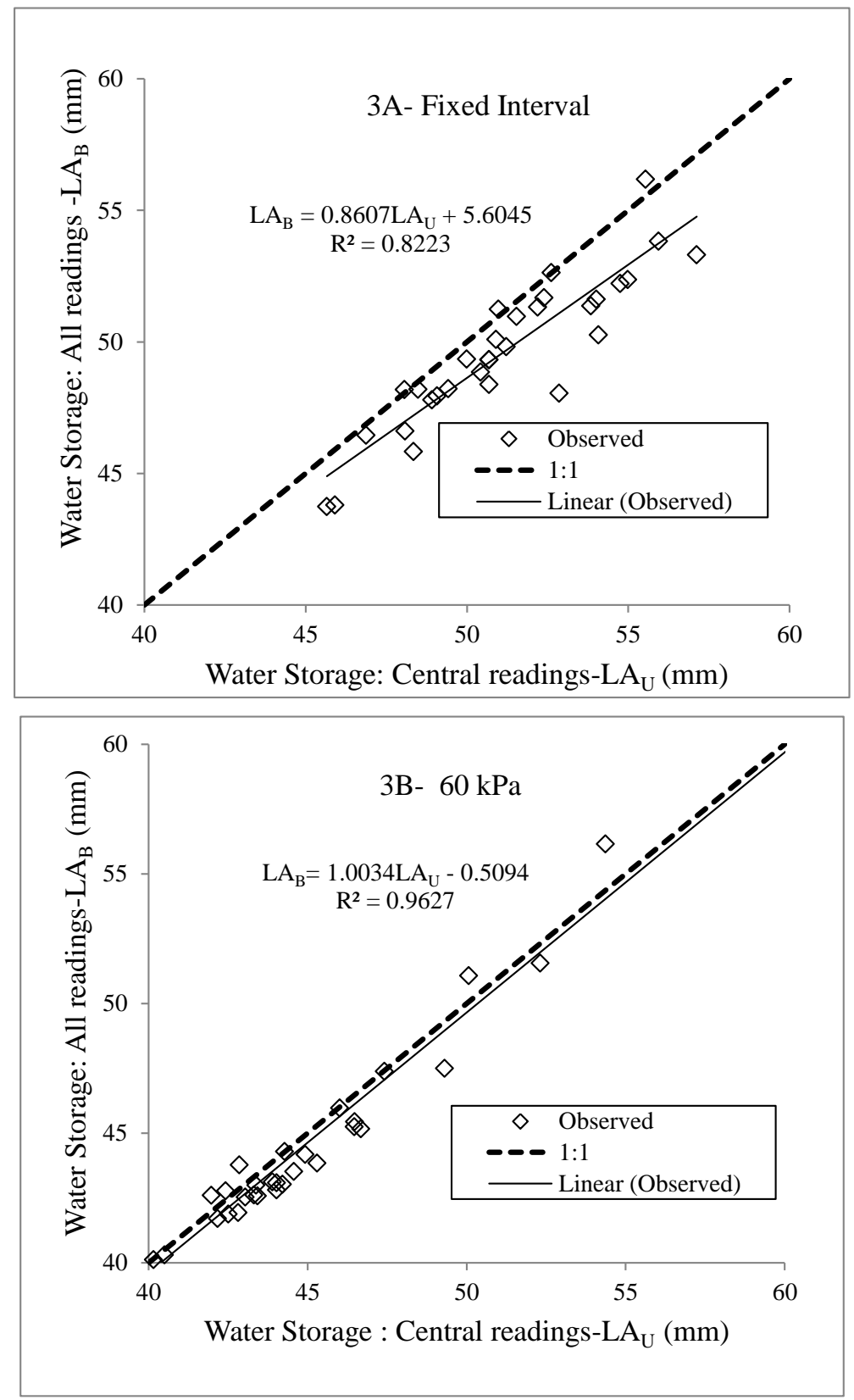

FIGURE 3. Two-Dimensional estimates of storage versus one -dimensional estimates observed under two irrigation criteria Fixed Interval ( $3 \mathrm{~A}$ ) and $60 \mathrm{kPa}$ tension (3B). 
Regression equations shown in Figures $3 \mathrm{~A}$ and $3 \mathrm{~B}$, that were adjusted to the two irrigation management regimes, are significantly different $(\mathrm{F}(2 ; 58)=3.45, \mathrm{P}=0.006)$. This difference confirms that spatial soil moisture distribution patterns beneath dripper lines submitted to different irrigation management practices (Fixed interval vs $60 \mathrm{kPa}$ ) are different.

Regarding to the "no dissipation of soil moisture lateral gradients" hypothesis, that may be applied for the treatment submit to a high frequency of water applications (fixed interval), this hypothesis would be confirmed by the non-equivalence of the two calculation processes, as indicated by existence of significant differences among estimates of water storage obtained by the one-dimensional and two-dimensional processes. The non-equivalence between these two calculation processes was confirmed by the statistically significant differences $\left(\mathrm{F}(2 ; 29)=26.7, \mathrm{P}=2 \times 10^{-7}\right)$ observed in Figure $3 \mathrm{~A}$ when comparing storage estimated values computed by the adjusted equation to storage values estimated by the straight line $1: 1$.

Thus, as illustrated in Figure 3A, even two or three days after the water applications, the soil moisture gradient that is formed during the drip irrigations, as described in several papers (OR \& COELHO, 1996, SOUZA \& MATSURA, 2004), results in an increased moisture concentration at the central part of the wetted strip, that makes storage estimates based on the readings of the six tensiometers installed at this central portion (LAU) overestimate the actual storage value, as determined by the reading of all 24 tensiometers (LAB).

Regarding to the "dissipation of soil moisture lateral gradients" hypothesis, that may be applied for the treatment submit to a low frequency of water applications (60kpa tension), this hypothesis would be confirmed by the equivalence of the two calculation processes, as indicated by the lack of significant differences among estimates of water storage obtained by the one-dimensional and two-dimensional processes. The equivalence between these two calculation processes was confirmed by the absence of statistically significant differences $(\mathrm{F}(2 ; 29)=2.04, \mathrm{P}=0.14)$ when comparing in Figure 3A storage estimated values computed by the adjusted equation to storage values estimated by the straight line 1:1.

This behavior confirms the dynamic characteristic nature of the wetted soil volume observed by OR \& COELHO (1996) and allows us to infer that, when the interval between drip irrigation events exceeds 10 days, determinations of water storage inside the wetted strip based on the one-dimensional process results on accurate storage estimates that are equivalent to those obtained by the two dimensional process.

\section{CONCLUSIONS}

Under high irrigation frequency conditions, in order to prevent overestimation of water storage in wetted strips, estimates obtained by the one-dimensional sampling method must be corrected by means of empirical equations similar to the ones developed in this study.

For larger irrigation intervals (lower soil moisture content), the one-dimensional and twodimensional processes provide equivalent estimates of water storage within the wetted soil strip beneath dripper lines of irrigated coffee orchards.

\section{ACKNOWLEDGMENT}

To the Coffee Research Consortium (Consórcio Pesquisa Café), the Foundation to Support Research from the State of Minas Gerais (Fundação de Amparo à Pesquisa do Estado de Minas Gerais FAPEMIG) and the National Council for Scientific and Technological Development (Conselho Nacional de Desenvolvimento Científico e Tecnológico - CNPq) for the financial support to this research.

\section{REFERENCES}

ALLEN, R.G.; PEREIRA, L.S.; RAES, D.; SMITH, M. Crop Evapotranspiration - guidelines for computing crop water requirements. Irrigation and Drainage. Rome: Food and Agriculture Organization of the United Nations, 1998. 300 p. (Paper, 56). 
BAKKER, G.; PLOEG, M.J. van der; DE ROOIJ, G.H.; HOOGENDAM, C.W.; GOOREN, H. P.A.; HUISKES, C.; KOOPAL, L.K.; KRUIDHOF, H. New polymer tensiometers: measuring matric pressures down to the wilting point. Vadose Zone Journal, Madison, v.2, n.6, p.196-202, 2007.

BARRETOS, G.V.C.; SAKAI, E.; PIRES, M.C.R.; ARRUDA, B.R. Técnica de avaliação de bulbo úmido por múltiplos cortes em trincheira. Irriga, Botucatu, v.13, n.2, p.160-169, abr/jun. 2008.

BRITO, A. dos S.; LIBARDI, P.L.; MOTA, C.A.; MORAES, S.O. Desempenho do tensiômetro com diferentes sistemas de leitura. Revista Brasileira de Ciência do Solo, Viçosa, v.33, n.1, p.17-24, 2009.

COELHO, E.F.; SILVA, A.J.P. da.; MIRANDA, J.H. Definição do posicionamento de sensores para monitoramento da água no solo em bananeira irrigada por diferentes sistemas de irrigação localizada. Engenharia Agrícola, Jaboticabal, v.30, n.4, p.608-618, jul./ago. 2010.

CONAB. COMPANHIA NACIONAL DE ABASTECIMENTO. Avaliação da safra agrícola cafeeira$1^{a}$ estimativa - Janeiro/2011. Disponível em:

<http://www.conab.gov.br/OlalaCMS/uploads/arquivos/11_01_06_08_52_41_boletim_cafe_1a_estimati va_safra_2011.pdf>. Acesso em: 4 mar. 2011.

CRUZ, T.M.L.; TEIXEIRA, A.D.S.; CANAFÍSTULA, F.J.F.; SANTOS, C.C.; OLIVEIRA, A.D.S.; DAHER, S. Avaliação de sensor capacitivo para o monitoramento do teor de água do solo. Engenharia Agrícola, Jaboticabal, v.30, n.1, p.33-45, jan/fev. 2010.

DANTAS, A.A.A.; CARVALHO, L.G. de.; FERREIRA, E. Classificação e tendências climáticas em Lavras, MG. Ciência e Agrotecnologia, Lavras, v.31, n.6, p.1862-1866, nov/dez. 2007.

GENUCHTEN, M. T. VAN A closed-form Equation for prediting the hydraulic conductivity of unsaturated soils. Soil Science Society of America Journal, Madison, v. 44, n. 5, p. 892-898, sept. 1980.

LOPES, L. N.; MARTINS, E.; SANTORO, B.L.; SOUZA, C.F. Caracterização da distribuição da água no solo para irrigação por gotejamento. Irriga, Botucatu, v. 14, n. 4, p. 564-577, out/dez. 2009.

MONTOVANI, E. C.; BERNARDO, S.; PALARETTI, L.F. Irrigação princípios e métodos. Viçosa: Editora da UFV, 2007. 358 p.

NASCIMENTO, L.L. do; MARTINS, E.; SANTORO, B.L. de; SOUZA, C.F. Caracterização da distribuição da água no solo para irrigação por gotejamento. Irriga, Botucatu, v.14, n.4, p.564-577, out/dez. 2009.

OR, D.; COELHO, E.F.O. Soil water dynamics under drip irrigation: Transient flow and uptake models. Soil Science Society of America, Madison, v.39, n.2, p.2017-2025, 1996.

PAVANI, L.C., LOPES, A. S., GALBIERO, R, B. Manejo da Irrigação na cultura do feijoeiro em sistemas de plantio direto e convencional. Engenharia Agrícola, Jaboticabal, v.28, n.1, p.12-21, jan/mar. 2008.

SOUZA, C.F.; FOLEGATTI, M.V. Spatial and temporal characterization of water and solute distribution patterns. Scientia Agricola, Piracicaba, v.67, n.1, p.9-15, jan/feb. 2010.

SOUZA, C.F.; MATSURA, E.E. Distribuição da água no solo para o dimensionamento da irrigação por gotejamento. Revista Brasileira de Engenharia Agrícola e Ambiental, Campina Grande, v.8, n.1, p.7-15, 2004.

SOUZA, C.O.L.; MANTOVANI, C.E.; SOARES, A.A.; RAMOS, M.M.; FREITAS, L.S.P. Avaliação de sistemas de irrigação por gotejamento, utilizados na cafeicultura. Revista Brasileira de Engenharia Agrícola e Ambiental, Campina Grande, v.10, n.3, p.541-548, 2006.

TAGLIAFERRE, C.; OLIVEIRA, R.A. de; OLIVERIA, E.M. de; BAPTESTINI, C.B; SANTOS, L. da C. Desempenho do irrigâmetro no manejo da água de irrigação na cultura do feijoeiro. Revista Caatinga, Mossoró, v.23, n.3, p.110-117, jul./set. 2010.

TEIXEIRA, A.S.; COELHO, S.L. Desenvolvimento e calibração de um tensiômetro eletrônico de leitura automática. Engenharia Agrícola, Jaboticabal, v.25, n.2, p.367-376, maio/ago. 2005. 